\title{
The utility of flow cytometry for potable reuse Nicole Rockey ${ }^{1}$, Heather N Bischel ${ }^{2}$, Tamar Kohn ${ }^{3}$, Brian Pecson ${ }^{4}$ and Krista R Wigginton ${ }^{1}$
}

Protecting public health from pathogens is critical when treating wastewater to drinking water standards (i.e., planned water reuse). Viruses are a principal concern, yet real-time monitoring strategies do not currently measure virus removal through reuse processes. Flow cytometry (FCM) has enabled rapid and sensitive bacteria monitoring in water treatment applications, but methods for virus and protozoa monitoring remain immature. We discuss recent advances in the FCM field and FCM applications for quantifying microorganisms in water. We focus on flow virometry (FVM) developments, as virus enumeration methods show promise for water reuse applications. Ultimately, we propose FVM for near real-time monitoring across treatment to more accurately validate virus particle removal and for pilot studies to characterize removal through understudied unit processes.

\footnotetext{
Addresses

${ }^{1}$ Department of Civil and Environmental Engineering, University of Michigan, Ann Arbor, MI, USA

${ }^{2}$ Department of Civil and Environmental Engineering, University of California, Davis, CA, USA

${ }^{3}$ Laboratory of Environmental Chemistry, School of Architecture, Civil and Environmental Engineering (ENAC), École Polytechnique Fédérale de Lausanne (EPFL), Lausanne, Switzerland

${ }^{4}$ Trussell Technologies, Inc., Oakland, CA, USA
}

Corresponding author: Wigginton, Krista R (kwigg@umich.edu)

\section{Current Opinion in Biotechnology 2019, 57C:42-49}

This review comes from a themed issue on Environmental biotechnology

Edited by Per Halkjær Nielsen and Lutgarde Raskin

https://doi.org/10.1016/j.copbio.2018.12.009

0958-1669/৫ 0001 Elsevier Ltd. All rights reserved.

\section{Introduction}

Wastewater is increasingly used as an alternative water source to meet potable needs [1-3], giving rise to new challenges in assuring public health. Pathogenic microorganisms are of principal concern in wastewater reuse due to the acute health risks they pose to consumers. Virus removal, in particular, is a major driver in the regulation and design of planned potable water reuse because they are present in high concentrations in wastewater [1,4-6], and their small size (20 nm to over $200 \mathrm{~nm}$ ) makes them difficult to remove [7]. Depending on the intended application and project location, reuse regulations and guidelines for virus removal range from 8- to 13logs or more from raw or treated wastewater to finished water $[4,5,8]$.

Ideally, pathogens would be monitored directly in finished drinking water to demonstrate the water is safe; however, this is infeasible due to the extremely low pathogen concentrations in safe finished water (e.g., $10^{-7}$ enteric viruses/l [1]). Instead, individual unit processes in the treatment train are allotted log removal credits for groups of pathogens, and the credits are summed across the treatment train. To maintain removal credits, the proper functioning of a unit process is ensured in real-time or near real-time by monitoring an easy-tomeasure surrogate parameter, such as turbidity or electrical conductivity. These surrogate parameters often underestimate actual microorganism removal. Virus removal credits, in particular, are very conservative. Consequently, potable water reuse treatment trains may be over engineered for pathogen removal because utilities cannot demonstrate the actual log reductions for common unit processes (e.g., biofiltration, ultrafiltration, reverse osmosis).

The water treatment field in general, and the wastewater reuse field in particular, would greatly benefit from technologies that accurately depict microorganism concentrations in real-time or near real-time and demonstrate their reductions through specific unit processes. We believe flow cytometry (FCM), a high-throughput technique that uses light scattering and fluorescence for particle detection [9], can fill some of these needs for microbe monitoring and will be increasingly applied for wastewater reuse monitoring. The main advantage of FCM over currently used surrogate parameters is that it directly detects microorganisms. The main advantages of FCM for reuse applications over other microbial detection techniques are that it is high-throughput, reproducible, and can concurrently enumerate different microorganism groups based on size and fluorescence properties. In this perspective, we review recent applications and advances in FCM for environmental monitoring. We discuss the three main pathogen groups but focus on virus detection using FCM, coined flow virometry (FVM), as we see this as an area ripe for advancement in coming years. In accordance with the demonstrated capabilities of FCM and FVM, we propose three-specific applications in potable water reuse. 


\section{Recent applications and advances in the use of FCM for bacteria and protozoa monitoring}

Bacteria enumeration via FCM is far more advanced than protozoa or virus monitoring in terms of experience, automation, and proof-of-concept research $[10,11]$. Bacteria in drinking and surface water matrices can effectively be monitored in real-time [12,13,14 $\left.{ }^{\bullet \bullet}\right]$ using flow cytometers with automated modules that routinely sample, stain, and enumerate bacteria with 15-min resolution [15]. Online bacteria monitoring via FCM in full-scale water treatment systems offers improved resolution, reproducibility, and statistical power over traditional bacteria monitoring methods such as heterotrophic plate counts [11]. Bacteria staining techniques aimed at assessing viability are now commonly applied to distinguish intact from membrane compromised bacteria [10]. Total and viable bacteria levels have been enumerated via FCM in various water types (Table 1). Total bacteria reductions of about two-logs have been reported across conventional wastewater treatment $[16,17]$, whereas a microfiltration unit process in a water reclamation facility can remove over five-logs $\left[18^{\circ}\right]$.

Unlike bacteria monitoring with FCM, measuring total protozoa populations has not been a focused area of research. This may be due to the presence of algae or other detrital material of similar size or fluorescent intensity $[19,20]$. Instead, protozoa FCM research has centered on quantifying the pathogens Cryptosporidium spp. and Giardia spp. in water because of their health and regulatory relevance. Depending on the sample matrix, significant concentration steps are required before FCM analysis to detect them [21,22]. Future work to address these limitations would help make protozoa monitoring using FCM more realistic as a real-time reuse monitoring strategy.

\section{Recent applications and advances in the use of FVM for virus detection Advances in FVM}

Improvements in sample preparation and FVM instrumentation are enabling quantification of total virus populations as well as specific viral strains. Most flow cytometers are unable to differentiate biological particles below approximately $300 \mathrm{~nm}$ from the background signal (i.e., noise) of the instrument-based solely on light scattering properties [23,24]. As a result, virus particles are commonly tagged with fluorescent dyes via antibodies, fluorescent proteins, or nucleic acid stains to facilitate detection. Even when stained or tagged, however, virus particle signals are at or near the background signals of some flow cytometers. The background signal arises from the optical, fluidic, and electronic components of the flow cytometer. Increased laser wattage, use of photomultiplier tubes (PMTs) or digital focusing systems (DFSs) in place of photodiode detectors, filtration of sheath fluid used during sample analysis, decreased internal chamber size, and continual instrument cleaning are all strategies to help reduce background signals for improved nanoparticle detection $\left[25^{\bullet \bullet}, 26\right]$. The difficulty in distinguishing a single virus particle from multiple virus particles in one FVM event [27] can be addressed via sample dilution [28], slower flow rates $(<1000$ events per second) [29], or smaller internal chamber size $\left[25^{\circ \bullet}\right]$. Building on these advances, the field of medical virology has conclusively demonstrated the utility of FVM to detect-specific virus particles, including HIV-1 [30,31], T4 and lambda phage [32], HSV-1 [33 ${ }^{\circ}$, Junin virus $\left[34^{\circ \bullet}\right.$ ], and filoviruses [35]. These studies have used specialized flow cytometers with stringent controls to ensure accuracy in distinguishing viral populations.

\section{Application of FVM to environmental samples}

Applications of FVM in medical virology tend to concentrate on the detection and characterization of targeted virus-species. Antibody-based fluorescent tagging, therefore, provides advantages in these applications due to its

\begin{tabular}{|c|c|c|c|}
\hline \multicolumn{4}{|c|}{ Microorganism concentrations measured by FCM/FVM in water samples that are relevant for potable reuse } \\
\hline \multirow[t]{2}{*}{ Sample type } & \multicolumn{2}{|c|}{ Bacteria } & \multirow{2}{*}{$\begin{array}{l}\text { Viruses } \\
\text { (counts/ml) }\end{array}$} \\
\hline & $\begin{array}{c}\text { Total } \\
\text { (counts } / \mathrm{ml} \text { ) }\end{array}$ & $\begin{array}{c}\text { Viable } \\
\text { (counts } / \mathrm{ml} \text { ) }\end{array}$ & \\
\hline Surface water & $10^{6}[12,50]$ & $10^{6}[51]$ & No data \\
\hline Groundwater & $1 \times 10^{3}$ to $5 \times 10^{6}\left[12,14^{\bullet \bullet}, 52,53\right]$ & $10^{5}[54]$ & No data \\
\hline Raw wastewater & 1.74 to $2 \times 10^{8}[16,17]$ & $8.4 \times 10^{7}[17]$ & $3.72 \times 10^{8}[16]$ \\
\hline Primary treated wastewater & $10^{8}\left[16,17,18^{\circ}\right]$ & $8.4 \times 10^{7}[17]$ & $10^{8}\left[16,18^{\circ}\right]$ \\
\hline Activated sludge & 2.24 to $3.3 \times 10^{9}[16,17]$ & 1.24 to $2.3 \times 10^{9}[16,17,55]$ & $10^{8}$ to $7.33 \times 10^{9}[16,41]$ \\
\hline Secondary treated wastewater & $\begin{array}{l}2.2 \times 10^{6} \text { to } 3.87 \times 10^{8} \\
{\left[16,17,18^{\circ}\right]}\end{array}$ & $1.7 \times 10^{6}$ to $10^{8}[16,17]$ & $10^{8}\left[16,18^{\circ}\right]$ \\
\hline Disinfected wastewater effluent & $10^{6}\left[16,18^{\circ}\right]$ & $10^{6}[16]$ & $10^{8}\left[16,18^{\circ}\right]$ \\
\hline Microfiltration effluent & $\leq 10^{2}\left[18^{\circ}\right]$ & No data & $7.3 \times 10^{6}[42]$ \\
\hline Reverse osmosis effluent & $<10^{2}\left[18^{\circ}\right]$ & No data & $<10^{4}\left[18^{\circ}\right]$ \\
\hline Finished drinking water & $10^{5}[56]$ & $70^{5}[51]$ & No data \\
\hline
\end{tabular}


specificity. Environmental FVM studies, in contrast, have typically focused on the enumeration of total virus particles. Here, nucleic acid staining is more applicable than antibody tagging because it theoretically targets all viruses in the sample. In reality, FVM fluorescence signals observed following nucleic acid staining are not consistent among viruses with variable genome types, genome sizes, and capsid structures.

In terms of environmental measurements, FVM has been used most extensively in marine biology for the enumeration of native marine virus populations stained with nucleic acid dyes [28,36-38]. FVM research in the marine biology setting has almost exclusively relied on dyes from the SYBR family. These are newer dyes with lower intrinsic fluorescence and improved nucleic acid signals compared to older dyes (e.g., DAPI; Table 2). SYTO, TOTO, and YOYO dyes, also newer dyes commonly employed by the medical virology field, are avoided in marine biology because they lose their binding affinity in samples with high ionic strength $[39,40]$. These dyes have yet to be explored with viruses in freshwater samples. Before analysis, marine virus samples are often pretreated with fixation, heat, and flashfreezing to improve virus particle fluorescence signals.

\section{FVM for water quality monitoring}

Water quality and water treatment researchers have drawn from procedures used in marine biology to enumerate total virus populations in wastewater and reclaimed water samples $\left[16,18^{\bullet}, 41^{\bullet}, 42\right]$. Overall, various combinations of SYBR Gold, SYBR Green I, and SYBR Green II have been employed, and pretreatments include sample flash-freezing, heating and incubation, and fixation $\left[16,41^{\circ}, 42\right]$. In complex samples such as wastewater, an additional virus disaggregation step, such as Tween 80 and sodium pyrophosphate pretreatment can improve virus enumeration $\left[41^{\circ}\right]$. An ultrasonication pretreatment step did not improve enumeration in activated sludge samples $\left[16,41^{\circ}\right]$ but did improve virus particle counts in settled wastewater samples [16].

FVM has been used to measure virus concentrations and removal rates for a range of treatment technologies in wastewater and water reuse systems (Table 1). No significant reduction in virus concentrations were observed through traditional wastewater processes via FVM $\left[16,18^{\circ}\right]$. Of note, total detectable virus concentrations were reduced by over four-logs through the microfiltration process of a reclamation facility in a recent study employing FVM [18 ${ }^{\circ}$. Reductions through the subsequent reverse osmosis unit processes were not measurable because the detection limit of the method had been reached $\left[18^{\circ}\right]$. In the same study, over four-logs of total detectable virus particles were removed through a membrane bioreactor process. At this point, infective and non-infective viral fractions have not been differentiated with FVM.

\begin{tabular}{|c|c|c|c|}
\hline \multicolumn{4}{|c|}{ Properties of nucleic acid stains and reference FCM studies that have used the specified stains for different analyses } \\
\hline Fluorescence dye & Quantum yield & $\begin{array}{l}\text { Fluorescence absorption/ } \\
\text { emission maxima }(\mathrm{nm})\end{array}$ & Examples of use in FCM \\
\hline \multicolumn{4}{|l|}{ Traditional dyes } \\
\hline Ethidium bromide (EB) & 0.14 (DNA) [57] & $518 / 605[58]$ & Bacteria and enumeration [59] \\
\hline $\begin{array}{l}\text { 4',6-Diamidino-2-phenylindole } \\
\text { (DAPI) }\end{array}$ & 0.34 (DNA) [58] & $358 / 461[58]$ & Bacteria enumeration [60] \\
\hline \multicolumn{4}{|l|}{ Hoechst family } \\
\hline Hoechst 33342 & 0.38 (DNA) [58] & $350 / 461[58]$ & Bacteria enumeration [60] \\
\hline \multicolumn{4}{|l|}{ Enhanced dyes } \\
\hline SYBR Gold & 0.7 (DNA, RNA) [62] & $495 / 537[62]$ & $\begin{array}{l}\text { Virus enumeration [37] } \\
\text { Virus/bacteria enumeration }\left[18^{\circ}\right]\end{array}$ \\
\hline SYBR Green I (SGI) & 0.8 (DNA), 0.4 (RNA) [40] & $494 / 521[40]$ & $\begin{array}{l}\text { Virus enumeration }[28,63] \\
\text { Bacteria enumeration }\left[17,55,64^{\circ}\right] \\
\text { Virus/bacteria enumeration }[16]\end{array}$ \\
\hline SYBR Green II (SGII) & 0.36 (DNA), 0.54 (RNA) [40] & $494 / 521[40]$ & Virus enumeration [41] \\
\hline \multicolumn{4}{|l|}{ SYTO family } \\
\hline SYTO 9 & $\begin{array}{l}0.6 \text { (DNA), } \\
0.2 \text { (RNA) [40] }\end{array}$ & $480 / 500[40]$ & $\begin{array}{l}\text { Bacteria sorting [65] } \\
\text { Bacteria enumeration [66] }\end{array}$ \\
\hline SYTO 13 & 0.4 (DNA), 0.4 (RNA) [40] & 488-491/509-514 [40] & $\begin{array}{l}\text { Bacteria sorting }[65,67] \\
\text { Virus sorting }[33,68]\end{array}$ \\
\hline \multicolumn{4}{|l|}{ тОто family } \\
\hline ТОТО-1 & 0.34 (DNA) [58] & $514 / 533[58]$ & Bacteria diversity [69] \\
\hline \multicolumn{4}{|l|}{ YOYO family } \\
\hline YOYO-1 & 0.52 (DNA) [58] & $491 / 509$ [58] & $\begin{array}{l}\text { Virus sorting [34] } \\
\text { Virus enumeration [39] }\end{array}$ \\
\hline
\end{tabular}




\section{Methodological challenges in FVM for water quality monitoring}

A number of challenges must be addressed before the utilization of FVM for water quality monitoring can be fully realized. One primary challenge is in confirming that all or most virus particles are actually being measured by FVM (i.e., avoiding false negatives). This is particularly difficult when enumerating virus particles with small genomes or single stranded genomes (e.g., ssRNA or ssDNA), which tend to emit smaller fluorescence signals. Studies often use transmission electron microscopy and/ or epifluorescence microscopy to confirm total virus particle counts obtained by FVM $\left[16,41^{\bullet}, 42\right]$. Spike additions of pure virus stocks into sample matrices are also critical to verify that the FVM method can effectively quantify the virus populations of interest. For example, Brown et al. $\left[41^{\circ}\right]$ measured total virus particle counts in samples with and without spike additions of T4 coliphage to assess recovery in activated sludge samples. Realizing the diversity of potential virus targets, we propose future studies spike virus cocktails, consisting of several different viruses, into samples to more accurately characterize the impacts of genome and structure type and size on recoveries.

Another significant challenge is minimizing false positives. These can be caused by cytometer background noise [28], particles that autofluoresce (e.g., colloids) [43], and biological particles that fluoresce when stained (e.g., microvesicles, gene transfer agents, or extracellular DNA) [44]. To address background noise of the machine, filtered and autoclaved samples are typically run through the cytometer and subtracted from stained samples $\left[41^{\bullet}, 42\right]$. Measuring the same sample before and after staining can help identify particles that are not virus particles. For biological samples, DNAse treatments have been used with limited success to reduce the likelihood of detecting free DNA $\left[41^{\circ}\right]$. Chloroform treatment of samples before the addition of DNAse could also prove beneficial by releasing membrane-associated nucleic acids from biological particles that may otherwise results in false positives (e.g., microvesicles, gene-transfer agents).

\section{Our vision of FCM in wastewater reuse applications}

Based on previous work in FCM for water monitoring, we envision at least three major applications of flow cytometry in the water reuse setting (Figure 1). First, we believe FCM will become an important near-real time surrogate measurement for validating log reduction values through physical treatment processes (e.g., filtration, sedimentation). Specifically, reductions of groups of particles with certain fluorescence properties could be used to represent the removal of microorganisms with the same FCM properties. For example, if flow cytometer measurements show a $99 \%$ reduction in detectable virus-like particles across a unit process, then two-log virus reduction will be granted for enteric viruses. Before this is feasible, research will need to establish whether reductions measured with FCM correlate with actual virus removal. As an example of our proposed approach, the four-log total virus removal measured by Huang et al. [18 $\left.{ }^{\bullet}\right]$ through microfiltration with FVM is similar to virus removal that has been achieved through microfiltration [45], although microfiltration virus removal has been highly variable (i.e., 0 to $>5-\log$ removal [46]). Where this approach can be applied in the reuse scheme will depend on detection methods for the particular cytometer and native virus particle concentrations. A wide range of FVM detection limits have been reported in various matrices, from 80 to $10^{4}$ particles $/ \mathrm{ml}\left[16,18^{\bullet}, 31\right]$. Beyond viruses, we imagine similar approaches could be made for bacteria and protozoa reductions across unit processes.

We also envision using FCM to continuously monitor particles of a certain size or fluorescence to help inform operators of changes in treatment plant influent or effluent quality. For example, potable reuse effluent could be continuously measured with FCM and trends in particle size distributions, fluorescence characteristics, or particle concentrations could be correlated with overall system performance. Aberrations in the FCM data would thus serve as an immediate warning for failures in the treatment train. This is similar to using turbidity measurements to detect changes in water quality, but FCM would provide more relevant and extensive information related to microbial water quality. Future research at actual plants should study how variations in FCM 'fingerprints' correlate with other indices used to assess influent water quality or overall treatment train performance.

Finally, we see FCM as a powerful tool for improved virus removal studies at the bench-scale and pilot-scale level. Currently, bench-scale and pilot-scale assessments of unit processes involve spiking in one or two surrogate viruses and measuring removal with culture-based methods. These studies are not only time consuming, but the selected surrogate viruses do not represent the behavior of all viruses of interest in water [47]. An alternative approach measures the reduction in spiked fluorescent latex bead concentrations [46], but these particles have little in common with virus particles. Instead, we propose using cocktails of bacteriophages of various sizes and genome types with stained nucleic acids that are readily detected by FVM for bench-scale and pilot-scale assessment. Alternatively, lab-synthesized virus-like particles identical to a variety of human pathogens in structure but containing nontoxic fluorescent tags instead of nucleic acids can be used as a cocktail for spiking experiments [48]. In either manner, the virus cocktails could be utilized to directly and rapidly measure virus log removals in pilot scale systems with FVM. An exciting application 


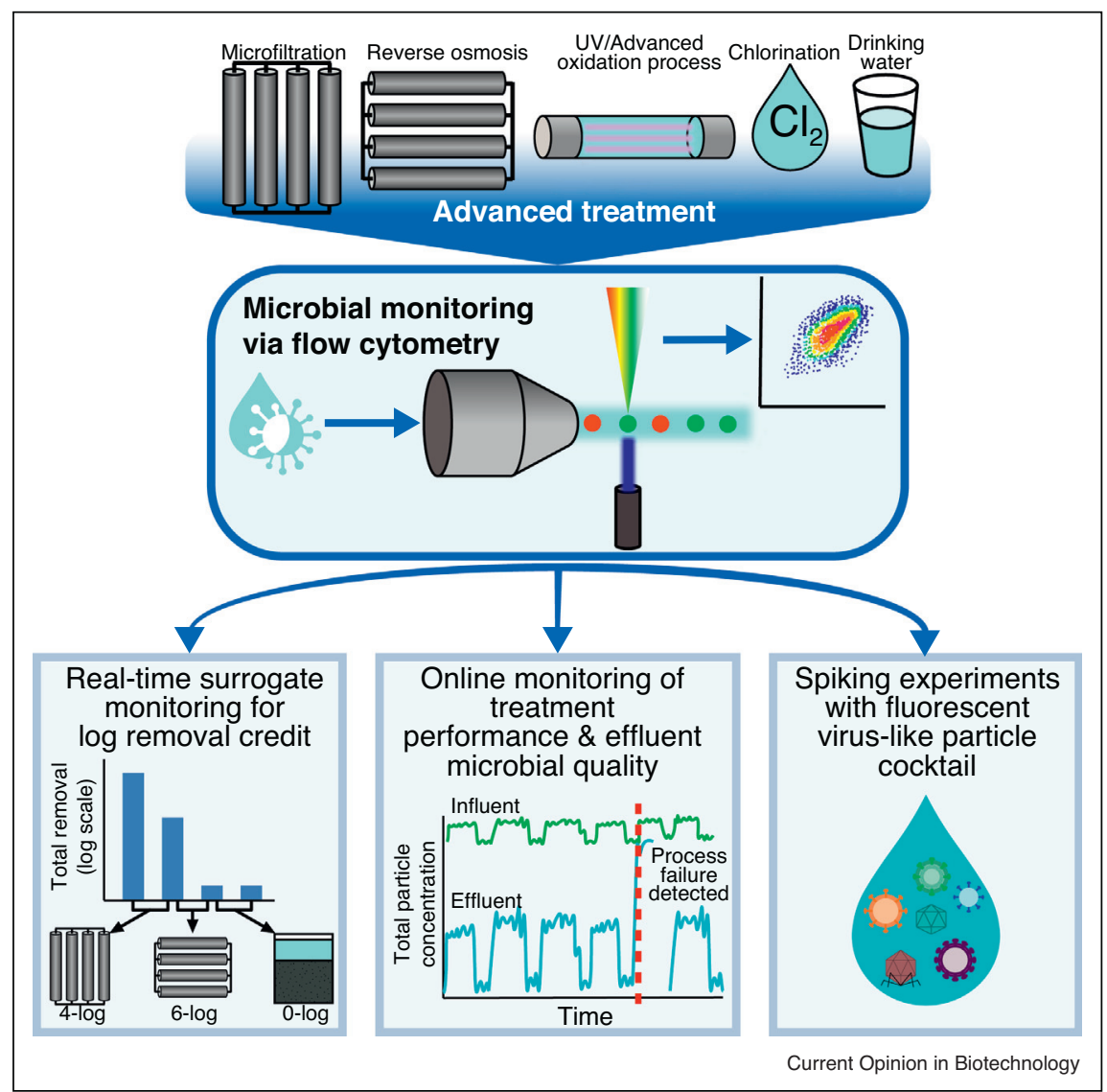

Three potential applications of FCM in an example advanced water treatment scheme. In the first application, log removal credits are maintained through unit processes by real-time particle monitoring. In the second application, online influent and effluent FCM monitoring detects aberrations in water quality and system performance. In the third application, cocktails of noninfective fluorescent viruses are added to water samples before unit processes to characterize virus removal.

of the virus-like particle spike cocktail is in assessing pathogenic virus reductions through biological treatment processes, which often also involve physical particle removal. Biological treatment likely propagates bacteriophage and thus increases total virus concentrations in treated water while pathogenic virus concentrations are concurrently decreasing. Therefore, measuring background total virus concentrations before and after biological processes by FVM would not provide an accurate assessment of pathogenic virus removal. Adding fluorescent virus particles that do not replicate could alleviate these issues and enable the accurate measurement of physical virus removal in unit processes where virus propagation occurs.

\section{Conclusions and future implications}

We envision that FGM will revolutionize how microbial monitoring is conducted through potable reuse, especially for virus detection. To bring this vision toward reality, research should compare instrument performance with different virus particle sizes of variable genome types (i.e., ssDNA, dsDNA, ssRNA, dsRNA) and assess fluorescence stains already employed in other applications. This research should be conducted in real waters with a range of characteristics, spanning from untreated municipal wastewater to finished reclaimed drinking water. Techniques should be developed that differentiate infective and noninfective virus particles with FVM, particularly as virus particles are inactivated through disinfection unit processes. A potential method for distinguishing infective virus particles could include the use of enzymatic pretreatment [49] to eliminate fluorescence from virus particles with degraded capsids. Research is also necessary to establish relationships between total particle concentrations measured with FCM and pathogenic microorganism concentrations. Finally, FVM monitoring should be studied through bench-scale unit processes, followed by testing at the pilot-scale, and should ultimately be applied in full-scale systems with automated monitoring. 


\section{Conflict of interest statement}

Nothing declared.

\section{Acknowledgements}

Project: WRRF 14-17. Funding agency: Water Environment \& Reuse Foundation (WE\&RF). Funding agency address: 1199 North Fairfax Street, Suite 410, Alexandria, VA 22314, USA.

\section{References and recommended reading}

Papers of particular interest, published within the period of review, have been highlighted as:

- of special interest

•• of outstanding interest

1. Trussell RR, Salveson A, Snyder SA, Trussell RS, Gerrity D, Pecson B: Potable Reuse: State of the Science Report and Equivalency Criteria for Treatment Trains. 2013.

2. Gerrity D, Gamage S, Jones D, Korshin GV, Lee Y, Pisarenko A, Trenholm RA, von Gunten U, Wert EC, Snyder SA: Development of surrogate correlation models to predict trace organic contaminant oxidation and microbial inactivation during ozonation. Water Res 2012, 46:6257-6272.

3. National Research Council: Water Reuse: Potential for Expanding the Nation's Water Supply Through Reuse of Municipal Wastewater. 2012.

4. California Department of Public Health: Title 22 and 17 California Code of Regulations. 2015.

5. Texas Water Development Board: Final Report - Direct Potable Reuse. 2015.

6. EPHC MHNRC and NRMMC: Australian Guidelines for Water Recycling - Augmentation of Drinking Water Supplies. 2008.

7. Pype M-L, Lawrence MG, Keller J, Gernjak W: Reverse osmosis integrity monitoring in water reuse: the challenge to verify virus removal - a review. Water Res 2016, 98:384-395.

8. World Health Organization: Potable Reuse: Guidance for Producing Safe Drinking-Water. 2017.

9. Shapiro HM: Practical Flow Cytometry. John Wiley \& Sons, Inc.; 2003.

10. Wang Y, Hammes F, De Roy K, Verstraete W, Boon N: Past, present and future applications of flow cytometry in aquatic microbiology. Trends Biotechnol 2010, 28:416-424.

11. Van Nevel S, Koetzsch S, Proctor CR, Besmer MD, Prest El, Vrouwenvelder JS, Knezev A, Boon N, Hammes F: Flow cytometric bacterial cell counts challenge conventional heterotrophic plate counts for routine microbiological drinking water monitoring. Water Res 2017, 113:191-206.

12. Hammes F, Broger $\mathrm{T}$, Weilenmann $\mathrm{H}-\mathrm{U}$, Vital M, Helbing $\mathrm{J}$, Bosshart U, Huber P, Peter Odermatt R, Sonnleitner B: Development and laboratory-scale testing of a fully automated online flow cytometer for drinking water analysis. Cytometry A 2012, 81A:508-516.

13. Brognaux A, Han S, Sørensen SJ, Lebeau F, Thonart P, Delvigne F: A low-cost, multiplexable, automated flow cytometry procedure for the characterization of microbial stress dynamics in bioreactors. Microb Cell Fact 2013, 12:100.

14. Besmer MD, Hammes F: Short-term microbial dynamics in a

-• drinking water plant treating groundwater with occasional high microbial loads. Water Res 2016, 107:11-18.

This work establishes the ability to assess microbial quality in near realtime using FCM. The authors measured total cell concentrations in raw groundwater and treated drinking water at 20-min resolution for 70 days using a fully automated flow cytometer and were able to show highly sensitive fluctuations in microbial concentrations due to impacted groundwaters. Such dynamics cannot easily be captured using culture-based methods.

15. Besmer MD, Epting J, Page RM, Sigrist JA, Huggenberger P, Hammes F: Online flow cytometry reveals microbial dynamics influenced by concurrent natural and operational events in groundwater used for drinking water treatment. Sci Rep 2016, 6:38462.

16. Ma L, Mao G, Liu J, Yu H, Gao G, Wang Y: Rapid quantification of bacteria and viruses in influent, settled water, activated sludge and effluent from a wastewater treatment plant using flow cytometry. Water Sci Technol 2013, 68:1763-1769.

17. Foladori P, Bruni L, Tamburini S, Ziglio G: Direct quantification of bacterial biomass in influent, effluent and activated sludge of wastewater treatment plants by using flow cytometry. Water Res 2010, 44:3807-3818.

18. Huang X, Zhao Z, Hernandez D, Jiang CS: Near real-time flow

- cytometry monitoring of bacterial and viral removal efficiencies during water reclamation processes. Water 2016, 8.

A promising study for the future of FVM in reuse; the authors displayed over four-log removal of viruses through reclaimed water membrane processes, indicating the sensitivity of FVM through certain physical treatment steps.

19. Keserue H-A, Füchslin HP, Wittwer M, Nguyen-Viet H, Nguyen TT, Surinkul N, Koottatep T, Schürch N, Egli T: Comparison of rapid methods for detection of Giardia spp. and Çryptosporidium spp. (Oo)cysts using transportable instrumentation in a field deployment. Environ Sci Technol 2012, 46:8952-8959.

20. Keserue H-A, Füchslin HP, Egli T: Rapid detection and enumeration of giardia lamblia cysts in water samples by immunomagnetic separation and flow cytometric analysis. Appl Environ Microbiol 2011, 77:5420-5427.

21. Vesey G, Hutton P, Champion A, Ashbolt N, Williams KL, Warton A, Veal D: Application of flow cytometric methods for the routine detection of cryptosporidium and giardia in water. Cytometry 1994, 16:1-6.

22. Ferrari BC, Veal D: Analysis-only detection of giardia by combining immunomagnetic separation and two-color flow cytometry. Cytometry A 2003, 51:79-86.

23. Chandler WL: Measurement of microvesicle levels in human blood using flow cytometry. Cytometry B Clin Cytom 2016, 90:326-336.

24. van der Pol E, Hoekstra AG, Sturk A, Otto C, van Leeuwen TG, Nieuwland R: Optical and non-optical methods for detection and characterization of microparticles and exosomes. $J$ Thromb Haemost 2010, 8:2596-2607.

25. Lippé R: Flow virometry: a powerful tool to functionally -. $\quad$ characterize viruses. J Virol 2018, 92.

Comprehensive review of recent work in FVM, including discussion of novel methods used to characterize viruses for a wide range of purposes, from development of virus maturation profiles to sorting of infective capsids for downstream analysis. Challenges in the field and recent technological advances are also a focus, with discussion points incorporating the advent of specialized instrumentation developed for nanoparticle detection and the use of dyes to improve fluorescent signal discrimination of viruses.

26. Lacroix R, Robert S, Poncelet P, Dignat-George F: Overcoming limitations of microparticle measurement by flow cytometry. Semin Thromb Hemost 2010, 36:807-818.

27. Van Der Pol E, Van Gemert MJC, Sturk A, Nieuwland R, Leeuwen Van TG: Single vs. swarm detection of microparticles and exosomes by flow cytometry. J Thromb Haemost 2012, 10:919-930.

28. Marie D, Brussaard CPD, Thyrhaug R, Bratbak G, Vaulot D: Enumeration of marine viruses in culture and natural samples by flow cytometry. Appl Environ Microbiol 1999, 65:45-52.

29. Zamora JLR, Aguilar HC: Flow virometry as a tool to study viruses. Methods 2018, 134-135:87-97.

30. Arakelyan A, Fitzgerald W, Margolis L, Grivel J-C: Nanoparticlebased flow virometry for the analysis of individual virions. $J$ Clin Invest 2013, 123:3716-3727.

31. Bonar MM, Tilton JC: High sensitivity detection and sorting of infectious human immunodeficiency virus (HIV-1) particles by flow virometry. Virology 2017, 505:80-90. 
32. Allen LZ, Ishoey T, Novotny MA, McLean JS, Lasken RS, Williamson SJ: Single virus genomics: a new tool for virus discovery. PLoS One 2011, 6:e17722.

33. El Bilali N, Duron J, Gingras D, Lippé R: Quantitative evaluation of - $\quad$ protein heterogeneity within herpes simplex virus 1 particles. $J$ Virol 2017, 91.

This group's work involves the use of FVM to sort HSV-1 exhibiting different amounts of tegument proteins to determine if protein content, in addition to genome presence, affects infectivity. Results of sorting and downstream analysis indicated consistently increased virus infectivity in capsids with greater VP16 or VP22 content.

34. Gaudin R, Barteneva NS: Sorting of small infectious virus -. particles by flow virometry reveals distinct infectivity profiles. Nat Commun 2015, 6.

By using YOYO-1 to stain Junin viruses, the authors demonstrate that nucleic acid stains can successfully discriminate ssRNA viruses from the background of a flow cytometer. It is important to note that a portion of the increased fluorescence observed may be due to YOYO-1 binding to the host ribosomal RNA packaged into Junin viruses.

35. Rossi CA, Kearney BJ, Olschner SP, Williams PL, Robinson CG, Heinrich ML, Zovanyi AM, Ingram MF, Norwood DA, Schoepp RJ: Evaluation of ViroCyt ${ }^{\circledR}$ virus counter for rapid filovirus quantitation. Viruses 2015, 7:857-872.

36. Brussaard CPD: Optimization of procedures for counting viruses by flow cytometry. Appl Environ Microbiol 2004, 70:1506-1513.

37. Chen F, Lu J, Binder BJ, Liu Y, Hodson RE: Application of digital image analysis and flow cytometry to enumerate marine viruses stained with SYBR gold. Appl Environ Microbiol 2001, 67:539-545.

38. Maat DS, van Bleijswijk JDL, Witte HJ, Brussaard CPD: Virus production in phosphorus-limited Micromonas pusilla stimulated by a supply of naturally low concentrations of different phosphorus sources, far into the lytic cycle. FEMS Microbiol Ecol 2016, 92 fiw136.

39. Marie D, Vaulot D, Partensky F: Application of the novel nucleic acid dyes YOYO-1, YO-PRO-1, and PicoGreen for flow cytometric analysis of marine prokaryotes. Appl Environ Microbiol 1996, 62:1649-1655.

40. Lebaron $\mathrm{P}$, Parthuisot N, Catala P: Comparison of blue nucleic acid dyes for flow cytometric enumeration of bacteria in aquatic systems. Appl Environ Microbiol 1998, 641725 LP-1730.

41. Brown MR, Camézuli S, Davenport RJ, Petelenz-Kurdziel E,

- $\quad$ vreås L, Curtis TP: Flow cytometric quantification of viruses in activated sludge. Water Res 2015, 68:414-422.

Work by these authors to enumerate viruses in activated sludge samples using FVM included the use of spike controls to validate FVM for enumerating virus particles. This study demonstrates the stringent checks (i.e. spike controls, DNase treatment, transmission electron microscopy) that can be used to reduce the presence of false positives when measuring absolute virus concentrations via FVM.

42. Huang X, Min JH, Lu W, Jaktar K, Yu C, Jiang SC: Evaluation of methods for reverse osmosis membrane integrity monitoring for wastewater reuse. J Water Process Eng 2015, 7:161-168.

43. Abzazou T, Salvadó H, Bruguera-Casamada C, Simón P, Lardín C, Araujo MR: Assessment of total bacterial cells in extended aeration activated sludge plants using flow cytometry as a microbial monitoring tool. Environ Sci Pollut Res 2015, 22:11446-11455.

44. Forterre P, Soler N, Krupovic M, Marguet E, Ackermann H-W: Fake virus particles generated by fluorescence microscopy. Trends Microbiol 2013, 21:1-5.

45. Francy DS, Stelzer EA, Bushon RN, Brady AMG, Williston AG, Riddell KR, Borchardt MA, Spencer SK, Gellner TM: Comparative effectiveness of membrane bioreactors, conventional secondary treatment, and chlorine and UV disinfection to remove microorganisms from municipal wastewaters. Water Res 2012, 46:4164-4178.

46. Antony A, Blackbeard J, Leslie G: Removal efficiency and integrity monitoring techniques for virus removal by membrane processes. Crit Rev Environ Sci Technol 2012, 42:891-933.
47. Gerba CP, Betancourt WQ: Viral aggregation: impact on virus behavior in the environment. Environ Sci Technol 2017, 51:7318-7325

48. Aumiller WM, Uchida M, Douglas T: Protein cage assembly across multiple length scales. Chem Soc Rev 2018, 47: 3433-3469.

49. Nuanualsuwan S, Cliver DO: Pretreatment to avoid positive RTPCR results with inactivated viruses. J Virol Methods 2002, 104:217-225.

50. Hammes F, Berney M, Wang Y, Vital M, Köster O, Egli T: Flowcytometric total bacterial cell counts as a descriptive microbiological parameter for drinking water treatment processes. Water Res 2008, 42:269-277.

51. Lautenschlager K, Hwang C, Ling F, Liu W-T, Boon N, Köster O, Egli T, Hammes F: Abundance and composition of indigenous bacterial communities in a multi-step biofiltration-based drinking water treatment plant. Water Res 2014, 62:40-52.

52. Sinreich M, Pronk M, Kozel R: Microbiological monitoring and classification of karst springs. Environ Earth Sci 2014, 71:563572.

53. Wang $\mathrm{Y}$, Hammes F, Egli T: The impact of industrial-scale cartridge filtration on the native microbial communities from groundwater. Water Res 2008, 42:4319-4326.

54. Nescerecka A, Juhna T, Hammes F: Identifying the underlying causes of biological instability in a full-scale drinking water supply system. Water Res 2018, 135:11-21.

55. Ziglio G, Andreottola G, Barbesti S, Boschetti G, Bruni L, Foladori $P$, Villa R: Assessment of activated sludge viability with flow cytometry. Water Res 2002, 36:460-468.

56. Prest El, Hammes F, Kötzsch S, van Loosdrecht MCM Vrouwenvelder JS: Monitoring microbiological changes in drinking water systems using a fast and reproducible flow cytometric method. Water Res 2013, 47:7131-7142.

57. Le Pecq J-B: Use of ethidium bromide for separation and determination of nucleic acids of various conformational forms and measurement of their associated enzymes. Methods Biochem Anal 1971, 20:41-86.

58. Sabnis RW: Handbook of Fluorescent Dyes and Probes. John Wiley \& Sons, Inc.; 2015.

59. Jernaes MW, Steen HB: Staining of Escherichia coli for flow cytometry: influx and efflux of ethidium bromide. Cytometry 1994, 17:302-309.

60. Monger BC, Landry MR: Flow cytometric analysis of marine bacteria with hoechst 33342. Appl Environ Microbiol 1993, 59:905-911.

61. Singer VL, Jones LJ, Yue ST, Haugland RP: Characterization of PicoGreen reagent and development of a fluorescence-based solution assay for double-stranded DNA quantitation. Anal Biochem 1997, 249:228-238.

62. Tuma RS, Beaudet MP, Jin X, Jones LJ, Cheung C-Y, Yue S, Singer VL: Characterization of SYBR gold nucleic acid gel stain: a dye optimized for use with $300-n m$ ultraviolet transilluminators. Anal Biochem 1999, 268:278-288.

63. Brussaard CPD, Payet JP, Winter C, Weinbauer MG: Quantification of aquatic viruses by flow cytometry. Manual Aquat Viral Ecol 2010:102-109. (Chapter 11).

64. Nescerecka A, Hammes F, Juhna T: A pipeline for developing

- $\quad$ and testing staining protocols for flow cytometry, demonstrated with SYBR Green I and propidium iodide viability staining. J Microbiol Methods 2016, 131:172-180.

The authors conduct a thorough investigation of various staining methods when assessing total and viable bacteria with FCM. Of note, the impor tance of stain concentrations, dilution reagents, heating temperature, and incubation are revealed, establishing the need for careful pretreatment methods to avoid detection of false positive or negatives.

65. Ben-Amor K, Heilig H, Smidt H, Vaughan EE, Abee T, de Vos WM: Genetic diversity of viable, injured, and dead fecal bacteria assessed by fluorescence-activated cell sorting and 16S rRNA gene analysis. Appl Environ Microbiol 2005, 71:4679-4689. 
66. Allegra S, Berger F, Berthelot P, Grattard F, Pozzetto B, Riffard S: Use of flow cytometry to monitor Legionella viability. Appl Environ Microbiol 2008, 74:7813-7816.

67. Servais P, Courties C, Lebaron P, Troussellier M: Coupling bacterial activity measurements with cell sorting by flow cytometry. Microb Ecol 1999, 38:180-189.
68. Loret S, El Bilali N, Lippe R: Analysis of herpes simplex virus type I nuclear particles by flow cytometry. Cytometry A 2012, 81:950-959.

69. Li WKW, Jellett JF, Dickie PM: DNA distributions in planktonic bacteria stained with TOTO or TO-PRO. Limnol Oceanogr 1995, 40:1485-1495. 